\title{
STRATEGI DINAS PERPUSTAKAAN DAN KEARSIPAN KALIMANTAN SELATAN DALAM MEMPROMOSIKAN EMERGENT LITERACY ANAK USIA DINI
}

\author{
Hardiyanti Pratiwi \\ Universitas Islam Negeri Antasari Banjarmasin \\ Email:diyankonayuki@gmail.com \\ Raudhatul Hasanah \\ Universitas Islam Negeri Antasari Banjarmasin \\ Email: adara.almeeraa@gmail.com \\ Nurul Qomariyah \\ Universitas Islam Negeri Antasari Banjarmasin \\ Email: nurulq369@gmail.com
}

Article received: 04 Desember 2019, Review process: 05 Februari 2020

Article published: 30 Maret 2020

\begin{abstract}
Many early childhood educators understand that early childhood must be able to read and write in adult definition. This understanding causes the practice of introducing reading and writing to children as if forced by the method of memorizing letters and using various cards. Educators seem to forget that in the process of acquiring the ability to read and write, children undergo gradual and ongoing experiences in their interactions with characters. This is known as the emergent literacy concept. The task of educators and parents at this time is to provide an environment that is rich in literacy for their children. Libraries also play an important role in promoting the concept of emergent literacy to the community. South Kalimantan Province Dispersip through Kids Library has a superior program in this endeavor. Through qualitative research, the authors inventory various programs run by kids libraries, namely providing a comfortable reading room, providing a variety of colorful games and ornaments, providing APE collections, providing various books for children, providing various programs such as school visits and presenting storytellers, opening services every day including holidays, presenting communicative and friendly librarians, to provide complete supporting facilities such as canteen, mosque, toilet's, and parks. These programs have proven to be able to increase the number of Kids Library visitors to thousands of children per month and make these children feel comfortable spending time in the library.
\end{abstract}


Keywords: Emergent Literacy, Kids Library, Early Childhood Literacy

\begin{abstract}
Abstrak
Tidak sedikit para pendidik PAUD memahami bahwa anak usia dini harus mampu membaca dan menulis dalam definisi orang dewasa. Pemahaman ini menyebabkan praktik pengenalan membaca dan menulis kepada anak seakan dipaksakan dengan metode menghapal huruf dan menggunakan berbagai kartu. Pendidik seakan terlupa bahwa dalam proses mengakuisisi kemampuan membaca dan menulis ini, anak menjalani pengalaman bertahap dan berkelanjutan dalam interaksinya dengan aksara. Hal ini dikenal dengan konsep emergent literacy. Tugas pendidik dan orang tua pada masa ini adalah menyediakan lingkungan yang kaya aksara bagi anaknya. Perpustakaan juga memegang peranan penting dalam mempromosikan konsep emergent literacy kepada masyarakatnya. Dispersip Provinsi Kalimantan Selatan melalui Kids Library memiliki program unggulan dalam usaha ini. Melalui riset kualitatif, penulis menginventarisir berbagai program yang dijalankan oleh kids library, yaitu menyediakan ruang baca yang nyaman, menyediakan berbagai permainan dan ornament warna warni, menyediakan koleksi APE, menyediakan berbagai buku untuk anak, menyediakan berbagai program seperti kunjungan sekolah dan menghadirkan pendongeng, membuka pelayanan setiap hari termasuk hari libur, menghadirkan pustakawan yang komunikatif dan ramah, hingga menyediakan fasilitas pendukung yang lengkap seperti kantin, musholla, toilet, dan taman. Berbagai program ini terbukti mampu meningkatkan jumlah pengunjung Kids Library hingga ribuan anak perbulannya dan membuat anak-anak tersebut merasa betah menghabiskan waktu di perpustakaan.
\end{abstract}

Kata Kunci: Emergent Literacy, Kids Library, Literasi AUD

\title{
PENDAHULUAN
}

Literasi - kemampuan membaca dan menulis - adalah keterampilan yang muncul yang dimulai sejak lahir. Bahkan bayi dan balita sedang dalam perjalanan menuju keaksaraan ketika mereka menulis dengan krayon atau bermain dengan buku, membalik halaman atau menunjuk ke gambar. Tanda-tanda awal membaca dan menulis ini disebut emergent literacy. (Weitzman \& Greenberg, 2010)

Dalam ulasan mereka atas literatur pengembangan literasi, Teale dan Sulzby (1986) mencatat bahwa dari akhir 1800-an hingga 1920-an literatur penelitian tentang membaca dan menulis hanya berfokus pada sekolah dasar. Namun, pada 1920-an, para pendidik mulai memahami bahwa masa usia dini sebagai periode persiapan untuk membaca dan menulis. 
Pada tahun 1925, Komite Nasional untuk Membaca menerbitkan referensi pertama yang memaparkan konsep kesiapan membaca (reading readiness).

Pengenalan istilah ini memunculkan dua arus penelitian yang berbeda tentang mempersiapkan anak-anak untuk membaca (Teale \& Sulzby, 1986). Sementara satu kelompok percaya bahwa kesiapan membaca adalah hasil dari kematangan (nature), kelompok lain berpikir bahwa pengalaman yang tepat dapat mempercepat kesiapan membaca (nurture). Sudut pandang yang berbeda ini menunjukkan perbedaan filosofis yang mendasari banyak penelitian tentang perkembangan anak selama bertahun-tahun.

Reading Readiness from the "Nature" Perspective merupakan teori yang mendominasi pada rentang tahun 1920-an hingga 1950-an. Teori ini menyatakan bahwa kesiapan membaca adalah hasil dari pematangan biologis. Dari perspektif ini, diyakini bahwa proses mental yang diperlukan untuk membaca akan muncul secara otomatis pada waktu tertentu dalam periode perkembangan (Teale \& Sulzby, 1986). Dengan demikian, pendidik dan orang tua disarankan untuk menunda pengajaran membaca sampai anak-anak mencapai usia tertentu.

Akhir 1950-an hingga 1960-an, teori dominan bergeser dari kesiapan membaca sebagai pematangan menuju kesiapan sebagai produk pengalaman. Para pendukung sudut pandang ini berpendapat bahwa jika anak-anak memiliki pengalaman yang sesuai, kesiapan membaca mereka dapat dipercepat. Teale dan Sulzby (1986) mengidentifikasi beberapa faktor yang berkontribusi terhadap perubahan ini:

1. Meningkatnya ketergantungan pada buku dan tes selama tahun-tahun pertama sekolah, yang telah digunakan oleh para maturationists sebagai alat intervensi;

2. peningkatan penelitian tentang anak usia dini yang menunjukkan bahwa mereka tahu lebih banyak daripada yang umumnya dipercayai;

3. keraguan akan kemapanan pendidikan Amerika karena Uni Soviet menjadi negara pertama yang melakukan perjalanan di luar angkasa; dan

4. pendapat pendukung kesetaraan sosial bahwa sejumlah besar anak-anak minoritas memiliki latar belakang budaya yang kurang beruntung dan harus menunggu sampai mereka tiba di sekolah untuk mengatasi kekurangan tersebut 
Awal tahun 1970-an, para peneliti mulai mempertanyakan kesesuaian praktik kesiapan membaca tradisional. Salah satu pelopor peneliti kemampuan membaca dan menulis anak usia dini adalah Marie Clay (Teale \& Sulzby, 1986). Clay (1966) pertama kali memperkenalkan istilah emergent literacy untuk menggambarkan ekspresi anak-anak terhadap buku dan perilaku ketika membaca dan menulis, meskipun anak-anak tidak dapat benar-benar membaca dan menulis dalam pengertian konvensional. Sedangkan konsep kesiapan membaca menyarankan bahwa ada titik waktu ketika anak-anak siap untuk belajar membaca dan menulis, emergent literacy menjadi teori baru yang menyatakan bahwa ada kontinuitas dalam pengembangan literasi anak-anak antara perilaku literasi awal hingga mereka dapat membaca secara mandiri (Idaho, Center on Developmental Disabilities, 1996).

Konsep emergent literacy telah secara bertahap menggantikan konsep kesiapan membaca (reading readiness). Hal ini memiliki dampak signifikan pada pendekatan pengajaran keaksaraan dalam program anak usia dini. Teori emergent literacy telah berkembang dari banyak penelitian dari bidang perkembangan anak, psikologi, pendidikan, linguistik, antropologi dan sosiologi. Emergent literacy telah memberikan definisi baru di bidang keaksaraan dan membuat pendidik, guru, dan orang tua sadar bahwa istilah kesiapan membaca tidak lagi menggambarkan secara memadai apa yang terjadi dalam perkembangan literasi anak usia dini (Teale, 1986).

Kesiapan membaca (reading readiness) merupakan istilah yang mengidentifikasikan keberadaan waktu ketika seorang anak siap untuk mulai belajar membaca dan menulis. Kedua hal tersebut adalah proses yang sulit untuk dipelajari anak usia dini. Anak-anak dianggap melek huruf ketika mereka memiliki kemampuan membaca dan menulis seperti halnya orang dewasa. Anak-anak yang dapat mengidentifikasi kata-kata tertulis tanpa petunjuk gambar dianggap pembaca. Demikian pula, anak-anak yang bisa mengeja kata-kata seperti orang dewasa dapat membacanya dianggap penulis. Definisi membaca dan menulis ini didasarkan pada sudut pandang orang dewasa.

Adapun Emergent literacy digunakan untuk menjelaskan pengetahuan anak tentang keterampilan membaca dan menulis sebelum mereka belajar membaca dan menulis kata-kata. Ini menandakan keyakinan bahwa, dalam masyarakat melek huruf, anak usia dini bahkan 
yang berusia satu dan dua tahun, sedang dalam proses menjadi melek huruf. Emergent literacy menunjukkan bahwa ada perkembangan keaksaraan yang berlangsung dalam diri anak. Ini adalah proses bertahap dan akan berlangsung seiring waktu. Melalui dukungan dari orang tua, pengasuh, dan pendidik, seorang anak dapat berhasil berkembang dari emergent literacy ke kesiapan membaca yang didefinisikan secara tradisional.

Menurut Whitehurst dan Lonigan, istilah emergent literacy digunakan untuk menunjukkan gagasan bahwa perolehan literasi dikonseptualisasikan sebagai perkembangan yang berkelanjutan (1998). Komunikasi orang tua-bayi ketika anak tersebut masih bayi (mis., Respons orang tua, nada emosi, dan perhatian bersama) memengaruhi perkembangan literasi selanjutnya (Dodici, Draper, \& Peterson, 2003). Ketika orang tua membacakan buku cerita untuk anak-anak, mereka belajar bahwa buku berisi kata-kata dan gambar yang menceritakan kisah. Ketika anak-anak menulis dengan krayon, mereka belajar bahwa tanda yang mereka buat memiliki makna. Banyak dari pengalaman sehari-hari usia dini yang memberi mereka pengetahuan dan keterampilan penting untuk pengembangan literasi. Keaksaraan ini muncul dimulai jauh sebelum anak-anak memasuki instruksi formal (Bennett, Weigel, \& Martin, 2002).

Secara historis, para pendidik percaya bahwa melek huruf dimulai ketika anak-anak masuk sekolah dan mulai pengajaran formal (Morrow, 2000). Anak-anak diasumsikan hanya mengembangkan melek huruf melalui instruksi langsung, seperti belajar membaca cerita, menulis surat dan mengembangkan keterampilan phonik untuk mengeluarkan kata-kata saat membaca dan menulis. Pengalaman awal dengan membaca dan menulis tidak dianggap sebagai bagian dari melek huruf. Belakangan, para pendidik mengakui pentingnya pengalaman-pengalaman ini sebagai keterampilan preliterasi yang merupakan prasyarat untuk belajar membaca dan menulis. Seperti disebutkan sebelumnya, para profesional sekarang menyadari bahwa emergent literacy dimulai saat lahir dengan beragam pengalaman (Erickson, 2000).

Belajar membaca telah lama dilakukan sebagai syarat untuk sukses di sekolah dan kehidupan. Anak-anak memulai jalur membaca ini sejak dini. Anak-anak belajar tentang fungsi dan proses membaca jauh sebelum mereka mengenal buku dan memahami makna teks. 
Keterampilan awal ini, dikenal sebagai Emergent Literacy (EL), termasuk pengetahuan dan kemampuan yang terkait dengan alfabet, kesadaran fonologis, representasi simbolik, dan komunikasi. Pemahaman konsep ini dibangun dari waktu ke waktu ketika anak-anak masih sangat muda, biasanya dari masa kelahiran hingga usia 5 tahun. Gagasan EL diperkenalkan oleh Marie Clay (1966) pada 1960-an. EL dikembangkan lebih lanjut pada 1980-an untuk mengkoreksi gagasan saat itu bahwa anak-anak tidak siap menjadi melek huruf sampai mencapai titik waktu tertentu, ditentukan oleh usia dan kematangan anak (Fosnot, 2013; Razfar \& Gutiérrez, 2003; Yaden, Rowe , \& MacGillivray, 2000). Sejak itu, EL telah diakui sebagai area konten penting dalam kurikulum prasekolah, dengan basis penelitian yang kuat mendukung penggunaannya (Blank, 2012; Connor, Morrison, \& Slominsk, 2006; Watson \& Wildy, 2014).

Konsep EL berkembang dalam rentang 1980-an hingga 1990-an dan sekarang diakui sebagai kombinasi dari developmentally appropriate practice (DAP) (Copple \& Bredekamp, 2009) dengan fokus memberikan kesempatan bagi anak-anak untuk belajar tentang literasi. DAP adalah kerangka praktik berbasis penelitian yang digunakan untuk merancang pengalaman pendidikan untuk anak-anak. Namun, meskipun ada bukti kuat tentang efektivitas dukungan dan pengajaran EL, hal tersebut jarang dipraktikkan dalam program anak usia dini (Powell, Diamond, \& Koehler, 2009).

Banyak pendidik anak usia dini telah mengakui pentingnya memberikan instruksi yang lebih eksplisit bagi siswa mereka yang meminta pelatihan dan dukungan (Dickinson \& Caswell, 2007; Nitecki \& Chung, 2013; Winsler \& Carlton, 2003). Karya terbaru oleh Nitecki dan Chung (2013) juga menunjukkan ketegangan antara mengajar EL, menggunakan DAP, dan membahas standar kurikulum baru. Tantangan-tantangan ini mungkin, setidaknya sebagian, disebabkan oleh kurangnya pemahaman pendidik tentang bagaimana faktor-faktor ini dapat bekerja secara harmonis. Peluang belajar keaksaraan awal lebih mungkin terjadi ketika guru memiliki basis pengetahuan EL dan pengembangan anak yang solid. Sebaliknya, guru prasekolah dengan pengetahuan terbatas tentang pengembangan literasi secara signifikan kurang mampu memberikan pengalaman seperti itu untuk anak-anak (Burgess et al., 2001; Dickinson, Freiberg, \& Barnes, 2011; Justice et al., 2008). 
Menanggapi perubahan pemikiran ini, pendidik dan orang tua didorong untuk menggunakan instruksi langsung dan kurikulum terstruktur dalam program anak usia dini dan TK untuk mempersiapkan anak-anak membaca. Dalam program kesiapan membaca, anakanak dianggap siap membaca ketika mereka telah memenuhi kompetensi sosial, fisik, dan kognitif tertentu (Morrow, 1997).

Kepedulian terhadap kualitas prasekolah dan kegiatan yang sesuai dengan perkembangan anak usia dini mensyaratkan pentingnya pemahaman tentang emergent literacy. Pendidik tidak boleh terjebak pada pemahaman bahwa PAUD harus membuat anak mampu membaca dan menulis. Kegiatan-kegiatan PAUD untuk mengakselerasi reading readiness nyatanya tidak didukung oleh penelitian tentang literasi dan bagaimana anak-anak mengakuisisinya. Akibatnya, banyak institusi PAUD yang menggunakan instruksi akademik formal secara tidak tepat (Freeman \& Hatch, 1989), dan penggunaan LKS tanpa kearifan merupakan bukti empiric akan hal ini. Dispersip Kalimantan Selatan memiliki program yang dapat mendukung kemunculan dan perkembangan emergent literacy bagi AUD dalam kids library yang digagasnya. Karena hal tersebut, penelitian tentang program ini menjadi penting agar institusi PAUD memiliki role model yang bagus dalam mempromosikan emergent literacy dalam institusi masing-masing.

\section{METODOLOGI}

Penelitian ini menggunakan pendekatan kualitatif deskriptif jenis studi kasus untuk memahami dan memaknai sebuah kasus secara intensif, komprehensif dan integrative dalam hal program Dispersip dalam mempromosikan emergent literacy untuk AUD di Kalimantan Selatan. Data dalam penelitian ini bersumber dari person, place dan paper. Person adalah narasumber yang mengetahui tentang program Dispersip dalam mempromosikan emergent literacy untuk AUD di Kalimantan Selatan mulai dari kepala Dispersip Kalimantan Selatan, kepala bidang hingga pustakawan. Sampelnya diambil secara purposive dan bersifat snowball. Sedangkan place adalah gambaran lokasi penelitian. Dari gambaran lokasi ini dapat diketahui karakteristik khusus yang merupakan kearifan local dalam program Dispersip dalam mempromosikan emergent literacy untuk AUD di Kalimantan Selatan. Paper adalah dokumen yang berkaitan dengan masalah penelitian baik berupa buku-buku, arsip sekolah, majalah dan bahan tertulis lainnya. Ada tiga metode yang dipakai dalam mengulkan data penelitian ini, yaitu: wawancara mendalam, observasi dan dokumentasi. Teknik analisis data dalam penelitian ini 
berpedoman dengan metode yang dikemukakan oleh Miles dan Huberman. Secara umum, ada tiga langkah yang akan ditempuh, yaitu reduksi data, display data dan penarikan kesimpulan atau verifikasi. Pengecekan keabsahan data diperlukan untuk membuktikan bahwa data yang didapatkan bersifat valid dan reliabel. Dalam penelitian ini, keabsahan data akan diuji melewati tahan uji kredibilitas (melalui perpanjangan pengamatan, peningkatan ketekunan, penggunaan bahan referensi dan triangiulasi), uji depenabilitas dan uji konfirmabilitas.

\section{HASIL DAN PEMBAHASAN}

\section{Program Dispersip dalam Mempromosikan Emergent Literacy}

Masyarakat Banjar merupakan masyarakat tutur. Bahasa banjar sebagai lingua franca tidak mempunyai huruf tersendiri. Ketika Raja Banjar memeluk agama Islam sekitar tahun 1526, mulailah aksara Arab digunakan dalam berbagai tulisan berbahasa melayu Banjar. Naskah kuno Banjar seperti hikayat Banjar, Undang-Undang Sultan Adam dan Tutur Candi menggunakan aksara Arab melayu dalam penulisannya. Namun dalam masyarakat Banjar, budaya lisan lebih mendominasi daripada budaya tulisan. Produk sastra lisan Banjar seperti madihin, baturai pantun, paribahasa, balamut, bapandung, hingga bakisah tumbuh subur di masyarakat.

Masyarakat yang terbiasa dengan budaya lisan ini mungkin memberi pengaruh pada kurangnya minat baca urang Banjar. Mereka lebih memilih untuk mendengar daripada membaca sendiri. Hal ini selaras jika kita menilik anggota perpustakaan daerah provinsi Kalimantan selatan yang hanya berjumlah 1.162 orang pada tahun 2010. Padahal jumlah penduduk Kalimantan Selatan pada tahun tersebut sebanyak 3.626.100 jiwa.

Kids Library yang sudah ada sejak berdirinya perpustakaan juga memiliki pengunjung yang sedikit. Namun setelah dilantiknya Dra. Hj. Nurliani Dardie sebagai kepala Dinas Perpustakaan dan Kearsipan Provinsi Kalimantan Selatan, Perpustakaan daerah mulai berbenah. Perpustaakan daerah melakukan renovasi agar lebih ramah bagi penyandang disabilitas. Inovasi paling mutakhir yang dilakukan oleh ibu Nurlianie adalah menghadirkan kids library dalam format baru yang dapat menarik minat anak. Kids library yang awalnya berada di lantai dua perpustakaan dipindah ke selasar perpustakaan daerah dengan ukuran yang lebih luas pada Oktober 2018. Tujuan ibu nurlianie pada saat itu hanya satu, yaitu agar anak-anak betah berada di perpustakaan. 
Saat ini, perpustakaan yang beralamat di Jalan A. Yani Km 6.5 Banjarmasin ini juga memiliki koleksi buku digital. Melalui pengembangan aplikasi iKalsel yang bisa diunduh dari google playstore secara gratis, perpustakaan yang familiar dengan nama perpus palnam ini hadir dalam bentuk digital untuk menyasar generasi milenial. Berbagai inovasi yang dilakukan pihak dispersip ini ternyata mampu mendongkrak pengunjung perpustakaan.

Segala inovasi yang dilakukan perpustakaan palnam ini ternyata secara tidak langsung juga mempromosikan kemunculan keaksaraan atau emergent literacy bagi anak usia dini. Perpustakaan yang identic dengan ruang yang penuh rak buku dan suasana yang senyap menjadi perpustakaan yang dipenuhi dengan suara anak-anak berlarian dengan suasana penuh kegembiraan. Berikut ini adalah program-program yang menjadi unggulan perpus palnam untuk mengembangkan literasi anak usia dini di Kalimantan selatan:

\section{Menyediakan ruang baca yang nyaman}

Melonjaknya jumlah pengunjung Kids Library Perpustakaan palnam hingga mencapai 3.595 orang perbulannya salah satunya dikarenakan ruang baca yang nyaman dengan dekorasi yang sedap dipandang. Kids library ini terbagi kepada 4 ruangan, yaitu ruang baca dan bermain utama, ruang baca dan bermain khusus anak di bawah 3 tahun, ruang koleksi buku dan baca utama dan ruang buku-buku yang belum dientri. Selain ruang yang terakhir, seluruh ruang yang ada di kids library bebas untuk diakses oleh pengunjung.

Dari segi pencahayaannya, ruang perpustakaan ini sangat terang namun teduh. Dinding pada ruangan berupa kaca tembus pandang sehingga cahaya dari luar dapat masuk ke dalam ruangan perpustakaan tersebut. Taman dan pepohonan mereduksi panas yang datang dari luar ruangan. Para pengunjung disuguhkan dengan suasana sejuk ketika memasuki ruang Kids Library karena ruangan tersebut dilengkapi dengan fasilitas AC dan kipas angin di berbagai sudut ruangan. Meja kursi tertata rapi untuk para pengunjung yang datang. Kursi dan meja kecil ini berwarna-warni dan terbuat dari plastik yang tidak membahayakan anak karena bobotnya yang ringan dan kokoh.

Dalam ruangan tersebut terdapat sofa dan bantal yang empuk untuk alas duduk atau bisa digunakan sebagai tempat bersandar. Ruangan ini juga dilengkapi dengan empat buah speaker yang biasa digunakan untuk memutar music instrumental atau lagu anak-anak. Tidak 
jarang anak-anak ikut menyayikan lagu yang diperdengarkan melalui speaker ini, karena lagu tersebut familiar bagi mereka.

Lantai perpustakaan juga dilapisi dengan karpet bertekstur sehingga tidak licin dan melatih sensori anak. Jika anak lelah membaca atau bermain, mereka bisa berguling-guling di lantai. Suasana santai seperti taman bermain ini memang sengaja diciptakan di kids library. Dengan suasana ini, tidak jarang ditemui anak-anak yang enggan pulang sehingga orang tuanya harus lebih lama menunggu dan mendampingi. Semua fasilitas di kids library memperhatikan aksesibilitas anak sehingga pengaturannya sangat teliti. Tidak ada fasilitas yang diletakkan di tempat yang terlalu tinggi sehingga tidak dapat dijangkau anak.

\section{Menyediakan berbagai permainan dan ornament warna warni}

Desain interior kids library memang memikat. Cat dinding berwarna warni namun sejuk di mata. Ada banyak ornament yang ditempelkan di dinding kaca perpustakaan dengan pengaturan yang harmonis. Ada bentuk bulan sabit, bintang, awan, berbagai macam binatang dan bentuk bentuk ornament lainnya yang menarik perhatian anak. Selain itu juga ada hurufhuruf alphabet berukuran besar, baik huruf balok maupun huruf kecil. Selain itu juga ada huruf-huruf hijaiyah dan doa-doa yang digantungkan di dinding. Keberadaan ornament warna warni ini juga merangsang perkembangan emergent literasi anak.

\section{Menyediakan koleksi Alat Permainan Edukatif (APE)}

Kids Library menyediakan berbagai macam alat permainan edukatif yang bebas dimainkan oleh anak. Dari observasi yang penulis lakukan, APE yang terdapat di Kids Library antara lain lego, puzzle, bongkar pasang, perosotan, jungkat-jungkit, mandi bola, kemah, dan rumah-rumahan yang tentunya disediakan untuk anak agar dapat bermain dengan puas. Semua Alat Permainan Edukatif ini diletakkan di dalam dua ruangan, yaitu di ruangan bermain utama yang digunakan untuk membaca santai dan bermain, dan di ruang bermain khusus untuk anak di bawah usia 3 tahun.

Keberadaan alat permainan edukatif ini menjadi pemicu utama ketertarikan anak untuk berkunjung ke perpustakaan. Banyak orang tua yang mengakui bahwa anak mereka ketagihan ke perpustakaan karena pada awalnya ingin bermain dan bersosialisasi dengan teman sebaya. Namun lambat laun, mereka mulai asyik membolak-balik buku dan 
mendengarkan cerita yang didedahkan orang tuanya. Perpustakaan anak memang menciptakan suasana yang cocok untuk anak bermain sekaligus belajar.

\section{Menyediakan berbagai buku untuk anak}

Ada banyak buku dengan berbagai katagori yang disediakan di Kids Library ini, mulai dari buku ensiklopedia, dongeng, fable, majalah anak, hingga buku-buku penunjang pelajaran seperti buku eksperimen sains. Bagi anak usia dini, perpustakaan juga menyediakan big book dan buku bergambar dengan kertas yang tebal sehingga tidak robek jika dipergunakan oleh anak. Buku-buku ada yang diletakkan di rak-rak yang terdapat di ruang bermain utama dan ruang bermain anak di bawah umur 3 tahun. Di dua ruang bermain ini, lebih banyak terdapat buku yang memuat banyak gambar. Hal ini dilakukan agar menarik minat anak terhadap buku. Adapun di ruang perpustakaan utama, terdapat rak buku besar yang berwarna warni. Di ruangan ini, meja dan kursi berwarna cerah tersusun rapi. Anak juga diperbolehkan membaca sambil rebahan karena lantai ruangan ini dilapisi karpet tebal.

Berdasarkan wawancara dengan kepala bidang pelayanan, anak usia TK dan SD sudah diperbolehkan membuat kartu anggota Kids Library. Namun biasanya, pustakawan menyarankan kepada orang tua agar anak yang membuat kartu anggota ini adalah anak yang sudah bisa membaca. Adapun bagi anak yang belum bisa membaca namun ingin meminjam buku perpustakaan, maka disarankan memakai kartu orang tuanya. Peraturan ini dibuat agar orang tua tertarik mendaftarkan diri sebagai anggota perpustakaan. Ketika orang tua meminjamkan buku untuk anaknya, aka nada timbul keinginan orang tua untuk membacakan cerita di rumah bagi anak-anaknya.

\section{Menyediakan berbagai program seperti kunjungan sekolah dan menghadirkan pendongen}

Perpustakaan memiliki beberapa layanan yang diberikan yaitu pelayanan umum, pelayanan anak, ada pelayanan keliling, adalagi tambahan pelayanan khusus yaitu pelayanan deposit dan pelayanan referensi. Untuk layanan perpustakaan keliling, perpustakaan memprioritaskan permintaan yang diajukan oleh PAUD-PAUD. Setelah jadwal terpenuhi, Kids Library keliling juga aktif mengunjungi PAUD-PAUD di kabupaten sekitar. Untuk perpustakaan keliling buku tidak bisa dipinjamkan dibawa pulang, hanya bisa dibaca ditempat 
saja. Dari wawancara diketahui bahwa Kids Library memiliki program yang sudah dijalankan dan akan dijalankan. Kids Library secara rutin mengadakan workshop bercerita yang sangat bermanfaat untuk memotivasi orang tua agar senang membacakan cerita untuk anaknya. Selain itu, Kids Library juga mengadakan kegiatan mendongeng oleh pendongengpendongeng professional. Kegiatan mendongeng ini selalu dibanjiri anak-anak bahkan hingga ruang perpustakaan tidak bisa menampung peserta yang berhadir. Perpustakaan juga memiliki program lomba mewarnai, lomba melukis, dan lomba puisi bagi anak-anak. (CW. KP. 03.06)

\section{Membuka pelayanan setiap hari termasuk hari libur}

Jadwal layanan kids library setiap hari Senin sampai dengan Kamis pada pukul 09:0016:00 WITA, dan hari Jum'at pada pukul 09:00-11:00 WITA dan buka kembali pada pukul 14:00-16:00 WITA, kemudian untuk hari Sabtu dan Minggu buka dari pukul 09:00-13:00 WITA. Segala fasilitas yang disediakan oleh Kids Library tidak hanya diperuntukkan bagi anggota perpustakaan, tetapi juga untuk semua pengunjung yang datang. Pengunjung hanya diminta untuk menuliskan nama di daftar pengunjung, kemudian akan diberikan kunci loker untuk menyimpan barang masing-masing. Setelah itu, pengunjung bebas mengakses semua fasilitas.

Pelayanan yang ramah dan maksimal ini membuat Kids Library menjadi pilihan utama untuk berlibur ketika akhir pekan. Beberapa pengunjung yang diwawancarai oleh penulis menuturkan bahwa mereka mengetahui keberadaan perpustakaan ini dari media sosial. Apalagi sekarang perpustakaan sudah memiliki akun Instagram sendiri untuk menyosialisasikan kegiatannya. Sejak itu, mereka menjadikan Kids Library sebagai destinasi liburan utama bagi anak mereka karena tempatnya dekat dari rumah, tidak memerlukan biaya dan tetap membuat anak senang.

\section{Menghadirkan pustakawan yang komunikatif dan ramah}

Para pustakawan memiliki tugasnya masing-masing, ada yang menjaga buku pengunjung dan mengarahkan pengunjung untuk menempatkan tas dan barang bawaan pribadi ke dalam loker yang telah disediakan, selain itu di setiap dinding terdapat tulisan tidak boleh membawa makanan dan minuman yang gunanya untuk menjaga kebersihan ruangan perpustakaan tersebut. Kemudian ada juga pustakawan yang khusus menjaga tempat 
peminjaman buku, ada juga pustakawan yang berkeliling untuk mengontrol kebersihan ruangan serta menyusun kembali buku-buku yang berada di meja untuk dirapikan.

Pustakawan juga aktif memberikan saran kepada orang tua dalam memilihkan buku untuk anaknya sesuai usia mereka. Interaksi pustakawan dengan orang tua juga terjadi dalam rangka memberikan pemahaman betapa pentingnya menumbuhkan kecintaan anak terhadap buku. Kecintaan untuk membaca ini jauh lebih penting dari kemampuan untuk membaca. Ketika anak cinta membaca, mereka akan terus membaca pada jenjang kehidupan selanjutnya. Sedangkan mampu membaca tidak menjamin mereka ma uterus membaca. buku juga bisa menjadi teman efektif untuk anak di saat orang tua mereka melakukan kesibukan sehari-hari. Dewasa ini, banyak orang tua yang menmbiarkan anak mereka bermain gadget ketika mereka sibuk. Dampaknya, speech delay banyak terjadi pada anak usia dini. Suatu hal yang dulunya jarang sekali terjadi ketika anak aktif berinteraksi dengan teman sebayanya.

Satu hal yang paling menonjol adalah sikap pustakawan yang selalu tampil dengan penuh senyum, padahal tingkah laku anak-anak ini cukup merepotkan. Mereka selalu menggunakan kata-kata positif dan sopan bahkan ketika menengahi anak yang berebut mainan atau menegur anak yang menggunakan fasilitas perpustakaan secara sembarangan.

Menyediakan fasilitas pendukung yang lengkap seperti kantin, musholla, toilet, dan taman

Selain fasilitas didalam perputakaan anak yang lengkap, di komplek perpustakaan ini juga terdapat kantin sehingga anak-anak dan pendampingnya yang lapar atau haus tidak perlu mencari makanan atau minuman di luar komplek perpustakaan. Harga yang ditawarkan pun terbilang murah. Kantin perpustakaan ini letaknya tidak jauh di belakang Kids Library. Perpustakaan juga menyediakan musholla yang terjaga kebersihannya tepat di belakang perpustakaan. Dari observasi yang penulis lakukan, musholla ini sangat membantu para orang tua untuk tetap mengerjakan kewajiban sholat mereka ketika anak-anak tidak ingin segera diajak pulang.

Toilet yang disediakan perpustakaan juga terjaga kebersihannya. Toilet ini tepat di samping pintu belakang perpustakaan. Toilet ada dua buah. Satu toilet untuk penyandang disabilitas, dan satu toilet untuk pengunjung umum. Taman di samping perpustakaan ikut 
memperindah pemandangan. Di kiri dan di kanan perpustakaan, ad ataman yang memiliki kolam ikan dan air mancur. Selain itu, taman juga dihiasi dengan patung rusa, monyet dan anak yang sedang membaca. Tidak jarang anak-anak bermain di taman ini di sore hari ketika cuaca panas sudah berkurang.

\section{Pembahasan}

Weibel (1992) melihat peran besar perpustakaan dalam mempromosikan literasi. Perpustakaan memberikan akses informasi tentang budaya, masyarakat, ekonomi, dan sejarah. Pustakawan berfungsi sebagai "penasihat pembaca" dengan menyarankan dan menafsirkan sumber daya di perpustakaan. Selain itu, perpustakaan menawarkan fasilitas belajar dan materi serta mempromosikan diskusi publik melalui sumber daya dalam koleksi mereka. Dalam upaya mereka untuk mempromosikan literasi di seluruh negeri, perpustakaan umum memiliki fokus untuk membantu dua segmen populasi yang membutuhkan bantuan dalam pengembangan keterampilan membaca; anak-anak prasekolah dan sekolah dasar dan orang dewasa dengan keterampilan membaca yang buruk.

Khusus untuk Anak-anak prasekolah dan sekolah dasar, sejumlah penelitian menunjukkan bahwa mengembangkan keterampilan emergent literacy selama masa kecil itu sangat penting. Membaca mungkin menyumbang sekitar sepertiga dari pertumbuhan kosa kata tahunan seorang anak (Anderson, 1995; Nagy \& Herman, 1987). Pada gilirannya, hal ini menjadi substansi kesuksesa mereka di masa mendatang. Anak-anak dengan lingkungan pengalaman bahasa yang buruk menunjukkan penurunan bertahap dan linear dalam tes pengembangan pendidikan prasekolah (Burchinal, Lee, \& Ramey, 1989).

Perpustakaan umum menyediakan akses bahan bacaan berkualitas tinggi dan pengalaman bahasa yang kaya semua anak tanpa membedakan latar belakang mereka. Anak usia dini dapat menggunakan perpustakaan sebagai persiapan membaca di sekolah. Perpustakaan menyediakan akses ke berbagai bahan bacaan dan kegiatan yang berhubungan dengan buku, seperti seni dan kerajinan, lagu, drama, bercerita, dan pertunjukan boneka. Kegiatan perpustakaan melibatkan anak-anak pada berbagai topik dan menyediakan kesempatan bagi anak-anak untuk memilih buku dan bahan bacaan mereka sendiri. 
Banyak perpustakaan mengadopsi perubahan teoritis pengembangan literasi ke dalam program anak-anak (Dowd, 1997). Para peneliti baru-baru ini telah beralih dari fokus dari kesiapan membaca (reading readiness) dan lebih berkonsentrasi pada emergent literacy; sebuah pendekatan yang lebih interaktif dan menyeluruh untuk pengembangan membaca yang menekankan pada perilaku membaca dan menulis yang alami yang ditunjukkan oleh anakanak prasekolah sebelum instruksi formal dimulai. Dalam konsep emergent literacy, anakanak didorong untuk menceritakan kisah mereka sendiri, menulis ide mereka sendiri, dan memainkan drama mereka sendiri sebagai cara untuk menumbuhkan keterampilan membaca awal mereka. Dowd (1997) memaparkan bahwa banyak perpustakaan umum yang merancang kembali program prasekolah mereka untuk mengakomodir emergent literacy melalui pembentukan komunitas keluarga literate.

Kupetz (1993) juga menunjukkan bahwa pustakawan dapat berperan penting sebagai sumber daya untuk orang tua dan guru. Pertama, mereka dapat mengumpulkan koleksi material yang cocok untuk pembaca usia dini seperti buku sajak, buku "tunjuk dan ucapkan", dan bigbook. Kedua, mereka dapat membimbing orang tua dan pengasuh anak profesional dalam memilih buku untuk anak usia dini. Selain itu, pustakawan juga dapat membantu orang tua yang merasa tidak nyaman membaca untuk anak-anak mereka dengan teknik read-aloud, membantu orang tua mengembangkan keaksaraan mereka sendiri, dan mendorong mereka untuk menikmati bacaan mereka sendiri.

Riset yang dilakukan oleh McKechnie (1996) menyelidiki kebiasaan penggunaan Kids Library perempuan berusia 4 tahun melalui studi etnografi. Dia mengamati dan merekam kunjungan Kids Library bersama ibu mereka dan melakukan wawancara dengan para ibu yang membuat buku harian tentang keterlibatan anak dengan bahan perpustakaan dan layanan perpustakaan lainnya. Hasil penelitian ini menunjukkan bahwa perpustakaan umum memiliki dampak signifikan pada perkembangan membaca anak-anak melalui penyediaan lingkungan yang kaya akan tulisan.

Fehrenbach, Hurford, Fehrenbach, dan Brannock (1998) mendesain studi eksperimental untuk mengevaluasi efektivitas program perpustakaan untuk mempromosikan EL pada AUD. Ada 29 anak berkulit putih dari kelas menengah yang berpartisipasi dalam 
penelitian ini. Hasil penelitian menunjukkan bahwa anak-anak yang mengikuti program perpustakaan menunjukkan tingkat kemunculan literasi dan keterampilan pra-membaca yang lebih tinggi, dan mampu membaca lebih banyak kata dengan benar. Penulis juga menyarankan agar pustakawan dapat bekerjasama dengan PAUD dalam pengembangan dan implementasi program yang mempromosikan EL pada anak usia dini.

\section{SIMPULAN}

Emergent Literacy adalah konsep berbeda dengan reading readiness. Pemahaman pendidik PAUD akan konsep ini sangatlah penting agar mereka dapat merumuskan pembelajaran yang mendorong pemerolehan kemampuan literasi anak usia dini. Selain itu, perpustakaan umum juga memiliki peran penting dalam menyosialisasikan konsep ini kepada para orang tua. Kids Library yang berada di bawah naungan Dispersip Provinsi Kalimantan Selatan memiliki program unggulan dalam mempromosikan emergent literacy di wilayahnya. Program tersebut antara lain menyediakan ruang baca yang nyaman, menyediakan berbagai permainan dan ornament warna warni, menyediakan koleksi APE, menyediakan berbagai buku untuk anak, menyediakan berbagai program seperti kunjungan sekolah dan menghadirkan pendongeng, membuka pelayanan setiap hari termasuk hari libur, menghadirkan pustakawan yang komunikatif dan ramah, hingga menyediakan fasilitas pendukung yang lengkap seperti kantin, musholla, toilet, dan taman. Dengan program-program ini, kids library mampu mendongkrak jumlah pengunjung secara signifikan dan menjadikan anak betah dalam lingkungan yang penuh aksara sehingga meningkatkan emergent literacy mereka.

\section{DAFTAR PUSTAKA}

American Library Association. (2000) “Kids and reading." Available online: http://www.ala.org/pio/factsheets/kidsucceed.html

Anderson, R. C. (1995). Research Foundations For Wide Reading. Urbana, IL: Center for the Study of Reading.

Barclay, Kathy; Benelli, Cecelia; \& Curtis, Ann. (1995). Literacy Begins At Birth: What Caregivers Can Learn From Parents Of Children Who Read Early. Young Children, 50 (4), 24-28.

Clay, Marie. (1966). Emergent Reading Behaviour. Unpublished doctoral dissertation, University of Auckland, New Zealand.

Dowd, F. S. (1997). Evaluating The Impact Of Public Library Storytime Programs Upon The Emergent Literacy Of Preschoolers. Public Libraries, 36 (6), 346-358.

Dzama, M. and Gilstrap, R.L. (1985, November). How Parents Prepare Their Children For A Formal Reading Program. Paper presented at the annual meeting of the Association for Children Education International, Omaha,NE. 
Ess, R.D., Holloway, S., Price, G.G. and Dickson, W.P. (1982). Family Environments And The Acquisitionof Reading Skills: Towards A More Precise Analysis. In L.M. Laosa \& I.E. Sigel (Eds.), Families as learningenvironments for children, pp. 87-113. NY: Plenum.

Fehrenbach, L. A., Hurford, D. P., Fehrenbach, C. R., and Brannock, R. G. (1998). Developing The Emergent Literacy Of Preschool Children Through A Library Outreach Program. Journal of Youth Services in Libraries, 12(1), 40-45.

Freeman, E.B., \& Hatch, J.A. (1989). Emergent Literacy: Reconceptualizing Kindergarten Practice. Childhood Education, 66, 21-24.

Hall, N. R. (1987). The Emergence Of Literacy. Portsmouth, New Hampshire: Heinemann Educational Books.

Idaho Center on Developmental Disabilities. (1996). What is emergent literacy? [Online]. Available: http://www.ets.uidaho.edu/cdhd/emerlit/intro.htm

Kupetz, B. N. (1993). A Shared Responsibility: Nurturing Literacy In The Very Young. School Library Journal, 39 (7), 28.

Leichter, H. (1984). Families As Environments For Literacy. In H. Goelman \& A. Oberg (Eds.), Awakeningto literacy, pp. 38-50. Portsmouth, NH: Heinemann Educational Books

McKechnie, L. (1996). Opening The Preschoolers' Doors To Learning: An Ethnographic Study Of The Use Of Public Libraries By Preschool Girls. Unpublished PhD. thesis. University of Western Ontario, London: Ontario.

McMahon, Rebecca. (1996). Introducing Infants To The Joy Of Reading. Dimensions of Early Childhood, 24(3), 26-29.

Morrow, Lesley Mandel. (1997). Literacy Development In The Early Years: Helping Children Read And Write. Boston: Allyn and Bacon.

National Association for the Education of Young Children. (1997). Helping Children Learn About Reading. [Online]. Available: http://npin.org/library/texts/home/learnabo.html [1997, September 25].

Rogoff, B. (1990). Apprenticeship In Thinking: Cognitive Development In Social Context. NY: Oxford UniversityPress

Snow, C.E., Barnes, W.S., Chandler, J., Goodman, J.F. and Hemphill, L. (1991). Unfulfilled Expectations:Home And School Influences On Literacy. Cambridge, MA: Harvard University Press.

Teale, W. (1986). The Beginnings Of Reading And Writing: Written Language Development During The Preschool And Kindergarten Years. In M. Sampson (Ed.), The pursuit of literacy: Early reading and writing. (1-29). Dubuque, Iowa: Kendall/Hunt Publishing Company.

Teale, W.H. and Sulzby, E. (1986). Emergent Literacy: Writing and reading. Norwood, NJ: Ablex.

Teale, W.H. and Sulzby, E. (1987). Access, Mediation And Literacy Acquisition In Early Childhood. InD. Wagner (Ed.), The future of literacy in a changing world, pp. 173-206. NY: Pergamon Pres 
Teale, William, \& Sulzby, Elizabeth. (1986). Emergent Literacy: Writing And Reading. Norwood, NJ: Ablex Publishing Corporation.

Weibel, M. C. (1992). The Library As Literacy Classroom: A Program For Teaching. Chicago: American Library Association.

Weitzman, E \& Greenberg, J (2010) Abc And Beyond: Building Emergent Literacy In Early Childhood Settings, Hanen Centre Publication, Toronto

Wigfield, A. and Asher, S.R. (1984). Social And Motivational Influences On Reading. In P.D. Pearson,R. Barr, M.L. Kamil \& P. Mosenthal (Eds.), Handbook of reading research, 1, 423-452. New York, NY:Longman. 